\title{
Opinion
}

\section{China's Policy on Dams at the Crossroads: Removal or Further Construction?}

\section{Chiyuan Miao ${ }^{1,2, *}$, Alistair G. L. Borthwick ${ }^{3}$, Honghu Liu ${ }^{1}$ and Jigen Liu ${ }^{1}$}

1 Changjiang River Scientific Research Institute, Changjiang Water Resources Commission, Wuhan 430010, Hubei, China; E-Mails: liuhh@mail.crsri.cn (H.L.); jigenliu@163.com (J.L.)

2 State Key Laboratory of Earth Surface Processes and Resource Ecology, College of Global Change and Earth System Science, Beijing Normal University, Beijing 100875, China

3 School of Engineering, The University of Edinburgh, The King's Buildings, Edinburgh EH9 3JL, UK; E-Mail: Alistair.Borthwick@ed.ac.uk

* Author to whom correspondence should be addressed; E-Mail: miaocy@bnu.edu.cn; Tel./Fax: +86-10-5880-4191.

Academic Editor: Sharon Megdal

Received: 2 December 2014 / Accepted: 12 May 2015 / Published: 19 May 2015

\begin{abstract}
During the past century, the number and scale of reservoirs worldwide has grown substantially to meet the demand for water and hydropower arising from increased population, industrialization, and urbanization. This is particularly the case in China, where reservoir construction increased rapidly after the Chinese economic reform and the introduction of open-door policies. On average, 4.4 large reservoirs with a capacity greater than $0.1 \mathrm{~km}^{3}$ were constructed per annum during the 1970s-1990s. This average reached 11.8 such reservoirs per annum in the 2000s. Considering the adverse impact of dams on rivers and riparian communities, various environmentalists and non-governmental organizations in China have begun to protest against the construction of dams. Now China's policy on dams is at a crossroads: Removal or further construction? In this paper, we systematically assess the construction of reservoirs in China and discuss the benefits and drawbacks of large-scale reservoir projects on several major rivers in China: The Yangtze River, the Yellow River and the Mekong River. Lastly, we provide a perspective on the future of reservoir development in China, taking into account natural conditions, renewable hydropower resources, and greenhouse gas emissions.
\end{abstract}

Keywords: reservoir; natural resource; eco-environment; China 


\section{Introduction}

During the past century, the number and scale of reservoirs worldwide has grown substantially to meet the demand for water and hydropower arising from increased population, industrialization and urbanization. It is reported that an average of two dams with heights exceeding $15 \mathrm{~m}$ were completed each day throughout the latter half of the 20th Century [1]. To date, over 50,000 such dams have been constructed globally, contributing to a total storage capacity of more than $8300 \mathrm{~km}^{3}$ [2]. At present, more than $60 \%$ of the world's rivers are dammed. According to the latest Global Reservoir and Dam (GRanD) database [3], the total capacities, by country, of the largest reservoirs capacity $\left(>0.1 \mathrm{~km}^{3}\right)$ are: Canada $\left(860.7 \mathrm{~km}^{3}\right)$, Russia $\left(811.8 \mathrm{~km}^{3}\right)$, USA $\left(767.5 \mathrm{~km}^{3}\right)$, Brazil $\left(530.3 \mathrm{~km}^{3}\right)$, and China $\left(451.0 \mathrm{~km}^{3}\right)$.

China currently has the largest agricultural economy in the world, as well as the largest population. Dams and reservoirs have played an important role in the recent socio-economic development of China, especially since the Chinese economic reform and the introduction of open-door policies in the late 1970s. Statistics show that reservoir construction in China developed rapidly over the past 30 years. For example, an average of 4.4 large reservoirs (of capacity greater than $0.1 \mathrm{~km}^{3}$ ) were constructed per annum during the 1970s-1990s (Figure 1). The pace of construction accelerated after 2000, with an average of 11.8 large reservoirs constructed each year during the 2000s. By 2011, China possessed 552 large capacity $\left(>0.1 \mathrm{~km}^{3}\right)$ reservoirs, 3269 medium capacity $\left(0.01-0.1 \mathrm{~km}^{3}\right)$ reservoirs, and 84,052 small capacity $\left(0.0001-0.01 \mathrm{~km}^{3}\right)$ reservoirs - with a total storage volume of $692.4 \mathrm{~km}^{3}$ [4]. The total capacity grew at a rate of $4.43 \mathrm{~km}^{3}$ per annum between 1973 and 1999, and the rate increased to $20.63 \mathrm{~km}^{3}$ per annum after 2000 (Figure 1). Although almost all the rivers in China are now regulated by reservoirs, China still has considerable capacity for further exploitation of its residual water resources. According to the China Water Resources Bulletins from 2006 to 2010, on average about $22.34 \%$ of the total available water resources in China were being exploited and utilized. There are very significant differences among the river basins: The northern basins have $>50 \%$ utilization and the Haihe river basin has even reached $>90 \%$ utilization.

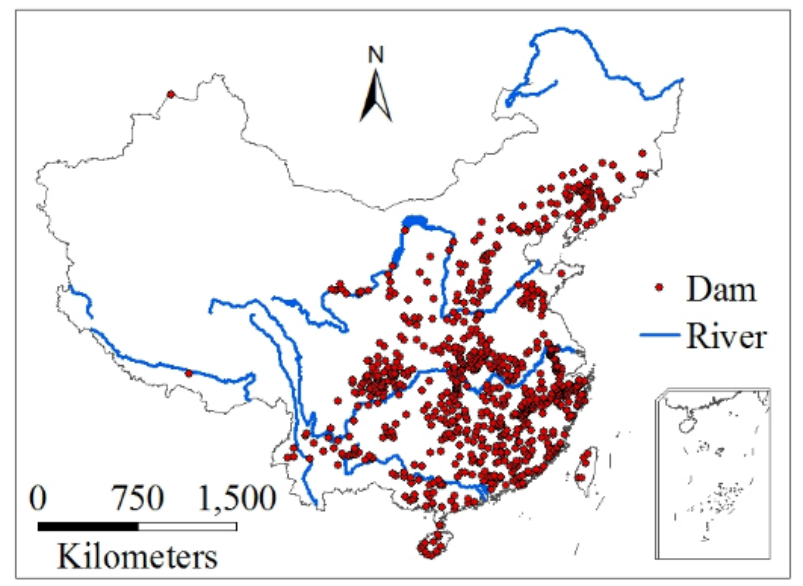

(a)

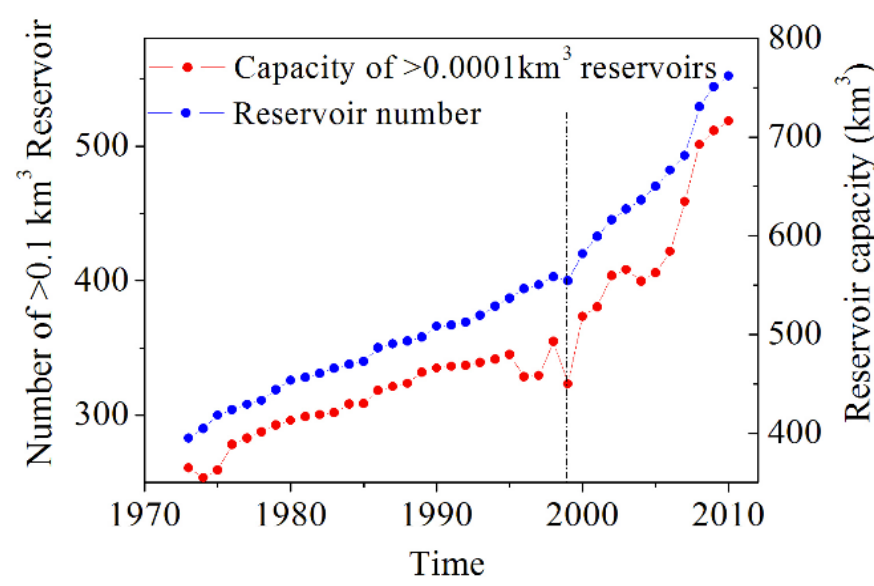

(b)

Figure 1. Distribution of dams throughout China in 2011 (a); and growth in the number of large reservoirs and the total capacity of reservoirs in China over the past 30 years (b). 


\section{Negative Impacts from Reservoir Development}

Reservoirs provide considerable socio-economic benefits by increasing the water supply available for municipal, industrial, and agricultural uses, controlling floods, and generating hydropower. At the same time, reservoirs also cause severe negative impacts, including biodiversity depletion, ecosystem degradation, and population displacement, etc. Illustrative examples are provided by the large-scale reservoir projects on the Yangtze River, the Yellow River, and the Mekong River in China.

The Three Gorges Reservoir (TGR) on the Yangtze River is the largest river regulation and hydroelectric power station in the world [5]. It cost more than US \$32 billion to construct and has an operational water level $110 \mathrm{~m}$ above the downstream river level. The TGR has a water surface area of $1080 \mathrm{~km}^{2}$, and the Three Gorges Dam controls a watershed area of over 1 million $\mathrm{km}^{2}$. The TGR has involved resettlement of more than 1.2 million local residents whose original habitations were located below the post-TGR upper water level. Although China has spent more than US \$6.3 billion on resettlement programs [6], complicated social challenges have arisen in helping the resettled former residents to adapt successfully to their new surroundings [7]. Water retained in the TGR has submerged an estimated 1300 sites of cultural and archaeological interest [8]. Construction of dams along the Yangtze River has impeded the spawning migration of certain fish species, leading to considerable reductions in the numbers of Chinese sturgeon (Acipenser sinensis) and Dabry's sturgeon (Acipenser dabryanus), and the possible extinction of the Chinese paddlefish (Psephurus gladius) [9]. Following the $156 \mathrm{~m}$ impoundment in 2007, the phytoplankton diversity index was observed to have decreased from $85.52 \%$ to $32.32 \%$ in tributaries in the TGR region. River flow in the Yangtze is generally slower than it was, leading to decreased scour of the river banks and blooms of toxic algae in tributaries. The vast area covered by the TGR has encouraged the spread of Oncomelania snails, which carry the parasitic disease schistosomiasis [10]. Another drawback of the TGR arises from its sheer scale-The immense hydrostatic loading created by the water behind the dam may induce seismic activity and the raised water level may result in landslides and erosional processes [11]. The potential risk of dam failure must also be considered because this would affect more than 70 million people living downstream. The dams also impaired the natural habitats of the now-extinct Chinese river dolphin Lipotes vexillifer [12].

The second example is provided by the cascade of more than 25 hydraulic projects along the Yellow River, with a total reservoir volume exceeding $55.75 \mathrm{~km}^{3}$. The Yellow River is the second largest river in China and contributes about $6 \%$ of global river sediment load [13]. Surface water evaporation from the upper and middle mainstream reaches of the Yellow River increased by approximately $68 \%$ after the construction of these reservoirs, resulting in a corresponding $2.3 \%$ decrease in water discharge [14]. The reservoirs in the Yellow River regulate both water discharge and sediment load, and control the amount of sediment deposited in the downstream channel. In the past, especially from the 1970s to the end of the 1990s, low flows in the lower Yellow River led to increased deposition that elevated the riverbed, prolonging the periods during which the river dried up. At Lijin, near the mouth of the river, no discharge was recorded for a total of 226 days in 1997 [15], which hastened the formation of the so-called 'suspended river' [11]. Moreover, the increased deposition aggravated the risk of major floods occurring in a river that has a long history of flood disasters. The cascade of reservoirs has greatly improved the water-sediment situation in the Yellow River: the occurrence of zero flow events has been reduced in recent years and the riverbed is no longer significantly rising. Consequently, most of 
reservoirs are gradually silting up, even after regular flushing. Furthermore, the barriers created by the dams have resulted in reductions in the numbers of certain indigenous species of semi-migratory fish [16]. It has been reported that about 13 fish species in the Yellow River are already almost extinct, including Cultrichthys erythropterus, Leiocassis crassilabris, Oryzias latipes, and Mastacembelus aculeatus [17].

The final and perhaps most contentious example is the dam cascade under construction along the Mekong River. For this case, we consider the river basin as a whole, rather than focusing solely on the upper reach in China. The Mekong River rises in Tibet and flows for $4800 \mathrm{~km}$ before eventually discharging into the Gulf of Thailand. The Mekong River Basin occupies a total area of 795,000 $\mathrm{km}^{2}$ and overlaps parts of China, Myanmar, Thailand, Laos, Cambodia, and Vietnam, and has a mean discharge rate of about $14,500 \mathrm{~m}^{3} / \mathrm{s}$. Since the early $1990 \mathrm{~s}$, China has been constructing a cascade of 8 dams with a projected total volume exceeding $40 \mathrm{~km}^{3}$ along a $750 \mathrm{~km}$ reach of the upper Mekong River (known as Lancangjiang in Yunnan province, China). The first four dams at Manwan, Dachaoshan, Jinghong, and Xiaowan were completed in 1993, 2003, 2008, and 2010. Other dams are presently under construction (see Table 1 for more details). The dams provide China with considerable hydropower, which will add up to more than 15,000 MW when all are operational, and should provide the benefits of flood prevention in the wet season and drought alleviation in the dry season through flow regulation. However, field measurements at hydrological stations along the Mekong River have indicated that operation of the Manwan dam may have altered downstream flow and sediment discharge characteristics, causing increased intermittent fluctuations during the dry season and a decline in sediment flux - The latter extending as far as the lowest reach of the Mekong River [18]. More recently, it has been suggested that the historical baseline low-flow levels of the Mekong River will have changed irrevocably by the time that China has completed construction of the upper Mekong cascade of dams [19]. Laos stands to benefit from about US \$25 billion in foreign investment and US \$2.6 billion in revenue per annum from exported energy [10], but at enormous environmental cost to the Mekong basin. The Xayaburi dam in Laos could render two species of giant catfish, Pangasianodon gigas and Pangasius sanitwongsei, extinct. There have been warnings that the dams under construction by China and planned by Laos will have dire consequences for the Tonlé Sap (or Great Lake) in Cambodia, which is connected by a tributary to the Mekong River [10]. In Cambodia, the loss of migratory fish species as a result of hydroelectric dams poses a direct threat to the security of food and income. It is estimated that no less than $80 \%$ of Cambodia's protein comes from the Tonle Sap basin, making Cambodia particularly vulnerable to any change in fish stocks in the basin. In the lower Mekong basin, seasonal flooding occurs at an estimated net cost of about US \$50 million per annum, and seasonal drought occurs at an estimated cost of about US \$10 million per annum solely in terms of loss of rice production [20]. Although completion of the entire cascade of dams will help regulate the usual flood cycle, it should be noted that there will be adverse repercussions for farmers who rely on nutrient-rich sediments being deposited during flood events [18]. With dams proposed along the lower stretches of the Mekong River, this situation is set to become even worse. Vietnam estimates that the Xayaburi dam will reduce nutrient-rich alluvial deposits in the Mekong Delta from 26 to 7 million tonnes per year [21]. This loss of soil nutrients for downstream farmers will result in reduced soil fertility, yields, and income [22]. Some researchers have raised the concern that the cascade of dams could damage the ability of the Mekong River to return to equilibrium, and propose further studies into the impact of the dam cascade on the water-sediment characteristics of the Lower Mekong River. Moreover, the dams may 
worsen the issue of saline intrusion in Vietnam. Currently, the last 10 to $20 \mathrm{~km}$ of the river experience salt intrusion, which impacts farmers in the area. The cumulative effects of another 11 planned hydropower schemes along the lower Mekong River could also be disastrous for smaller migratory fish species, leading perhaps to a more than $40 \%$ decrease in fish stocks $[23,24]$.

Table 1. China's 8-dam cascade along the upper Mekong River (Lancang River).

\begin{tabular}{ccccccc}
\hline Dam & $\begin{array}{c}\text { Catchment } \\
\text { Area }\left(\mathbf{k m}^{2}\right)\end{array}$ & $\begin{array}{c}\text { Mean Flow } \\
\text { Discharge } \\
\left(\mathbf{m}^{\mathbf{3}} / \mathbf{s}\right)\end{array}$ & $\begin{array}{c}\text { (Estimated) } \\
\text { Completion } \\
\text { Year }\end{array}$ & $\begin{array}{c}\text { Maximum } \\
\text { Height } \\
(\mathbf{m})\end{array}$ & $\begin{array}{c}\text { Total Reservoir } \\
\text { Capacity } \\
\left(\mathbf{m i l l i o n} \mathbf{~ m}^{\mathbf{3}}\right)\end{array}$ & $\begin{array}{c}\text { Installed Power } \\
\text { Capacity (MW) }\end{array}$ \\
\hline Gongguoqiao & 97,300 & 985 & 2012 & 130 & 510 & 750 \\
Xiaowan & 113,300 & 1,210 & 2011 & 292 & 14,560 & 4,200 \\
Manwan & 114,500 & 1,230 & 1996 & 132 & 920 & 1,500 \\
Dachaoshan & 121,000 & 1,230 & 2004 & 111 & 933 & 1,350 \\
Nuozhadu & 144,700 & 1,730 & 2014 & 261.5 & 22,400 & 5,500 \\
Jinghong & 149,100 & 1,840 & 2008 & 108 & 1,233 & 1,750 \\
Ganlanba & 151,800 & 1,880 & Before 2025 & 60.5 & - & 150 \\
Mengsong & 160,000 & 2,020 & - & 65 & - & 600 \\
\hline
\end{tabular}

\section{Discussion and Perspectives}

As a consequence of the negative impacts outlined above, some environmentalists and non-governmental organizations (NGOs) in China have begun to campaign against China's dam construction policy, influenced by the 'anti-dam' movement in the U.S. that began in the 1960s. These campaigners believe that the adverse impact of dams on rivers and riparian communities outweighs the benefits, and propose dam removal as the best way to restore healthy rivers and riverside communities in China. This idea rapidly propagated throughout China at the same time as dam construction accelerated after 2000 .

So now China's policy on dams is at a crossroads. Should China follow the economic, flood control, energy, and irrigation imperatives and continue to construct dams? Or should it reject further plans for construction and remove pre-existing dams in order to let the rivers run free, and hopefully return to halcyon days, as viewed from environmental and societal perspectives? It is particularly difficult for stakeholders in China to choose between the options because of the scale of the problems encountered whichever way the decision goes.

There is precedent for the removal of existing dams in developed countries. Hydropower in developed countries is comparatively mature, with those countries having already undergone the period of large-scale hydropower development. Moreover, most of the dams removed in developed countries were dilapidated, had existing problems, and/or were of small capacity. In our opinion, it is both unrealistic and inadvisable to reject arbitrarily all dams in China. Firstly, the natural hydrological conditions in China include a unique monsoon climate, highly non-uniform rainfall distribution, and strong peak river-flow variability. These factors have resulted in frequent drought and flood disasters throughout history. Dams are able to effectively attenuate peak flood discharges during the wet season, while adjusting to the competing water supply and ecological water demands of the middle and lower reaches of a river during the dry season. At the time of writing, dams and reservoirs in China provide flood 
protection to more than 310 million people and $3.2 \times 10^{5} \mathrm{~km}^{2}$ of arable land. Moreover, grain production from dam-related irrigation areas accounts for $\sim 70 \%$ of the total output of grain in China. If all dams were to be removed, the total indigenous grain output in China would be halved, and hundreds of millions of people could then face possible starvation.

Secondly, dams exploit China's abundant renewable hydropower resources, and the electricity produced has helped meet the rapid growth in energy demands associated with economic and societal development in China. The technically exploitable hydropower potential in China is about $2474 \mathrm{TWh} / \mathrm{yr}$, but the actual hydropower generated is about $565.5 \mathrm{TWh} / \mathrm{yr}$ [25]. The hydropower development ratio is only $22.86 \%$, far behind that of many developed countries, e.g., Italy (over 90\%), France (90\%), Japan (84\%), USA (80\%), and Germany (73\%). Moreover, the exploitable hydropower in the western provinces accounts for more than three-quarters of the total exploitable hydropower in China (Figure 1), but the hydropower development ratio there is less than $10 \%$. In order to bridge the gap between energy supply and demand while meeting its economic objectives as a developing country, China must increase its utilization of renewable energy, rather than relying on energy imports.

Thirdly, China has been the world's highest emitter of greenhouse gases since 2007. Global climate change has brought forward a new challenge for modern China. At present, most electricity in China is generated by coal-fired power stations, with only $9 \%$ originating from non-fossil-fuel sources in 2010 . China has pledged to reduce its carbon intensity (the amount of carbon dioxide produced per unit of economic growth) by $40 \%-45 \%$ of 2005 levels before 2020 [26]. In the case of the TGR, the huge levels of hydropower production can replace 50 million tons of coal equivalent consumption, 0.1 billion tons of $\mathrm{CO}_{2}, 2$ million tons of $\mathrm{SO}_{2}, 10,000$ tons of $\mathrm{CO}$, and 370,000 tons of nitrogen oxide, when compared with coal-fired power plants [6]. The 12th Five-Year Plan for 2011-2015, adopted by the National People's Congress of the People's Republic of China in March 2011, states that 15\% of energy will be generated from non-fossil-fuel sources by 2020. Considering the return on investment (ROI), development potential, and current development levels of nuclear, solar, and wind energy in China, the 12th Five-Year Plan pointed out clearly that $9 \%$ of China's energy will need to come from hydropower by 2020 . To meet this target, a massive expansion in hydropower will be needed.

The foregoing hydrological risk mitigation, energy security, and low carbon arguments mean that dam construction remains a necessity during the present stage of development in China. However, the authorities in China are increasingly aware of the painful lessons drawn from the failure in the past to achieve fully sustainable reservoir development, and are taking note of various perspectives including those of the international anti-dam movement as well as the international community of hydropower engineers and scientists. River basin authorities in China should consider making the following adjustments to their policies concerning reservoirs and dams:

(1) Processes for public and stakeholder engagement should be established. The involvement of society at large in decisions about dams is an inevitable consequence of social development, and it is important that the general public be encouraged to participate in the decision-making process. In particular, all relevant information should be assessed openly and objectively.

(2) Eco-environmental monitoring systems should be established for the entire period during which the dam is constructed, in operation, and decommissioned. China has started to construct such monitoring systems, and has already begun to reap the benefits. However, most of the current 
monitoring systems only serve reservoirs that are in operation or under construction. Reservoirs that are being decommissioned have so far tended to be ignored.

(3) Eco-environmental impact assessments conducted during studies of reservoir feasibility should be comprehensive and consider all the short- and long-term benefits and drawbacks. These assessments should take into account all competing interests - including positive and negative effects on the people in the upper, middle, and lower reaches of the affected river. This should encompass trans-boundary interests and involve dialogue between affected provinces and nations. Current environmental impact assessments focus heavily on the immediate, and often obvious, outcomes of reservoir construction and may not consider the longer-term effects on the physical and human ecology of an area. More comprehensive assessments would allow longer-term scientific and technical predictions to be coupled with political and social assessments in order to influence decisions over whether reservoirs can be built with minimal environmental impact and in a way that protects the social and environmental rights of affected communities. To date, such considerations have not been granted enough emphasis in the design and construction of dams in China.

(4) Eco-environmental impact and running benefits of existing reservoirs should be evaluated scientifically. Reservoirs provide considerable benefits; however they also unavoidably have severe ecological and societal impacts. Evaluation of existing reservoirs should include integrated input from experts in the fields of sociology, economics, and environmental science, and should also involve public participation. China has started to implement such integrated evaluations for representative reservoirs but, so far, the evaluations have involved only a limited number of experts. This has restricted publicity of the information and awareness of the relevant findings.

(5) Resettlement policies should be strengthened so that they fairly safeguard the legitimate rights, equity, and wellbeing of the people displaced by dams and reservoirs. This involves ensuring that displaced people are involved as stakeholders through consultation, participation, decision-making, and supervisory activities.

China's policy towards dams is at a crossroads. The way forward involves a sensitive compromise between satisfying the economic and societal demands for flood control, water supply, food, and energy security, while also achieving a more balanced approach to river-basin management that is in keeping with Nature as well as Mankind.

\section{Acknowledgments}

Funded By CRSRI Open Research Program (CKWV2013214/KY), the National Natural Science Foundation of China (41001166), 948 Project of Ministry of Water Resource (201306), and the State Key Laboratory of Earth Surface Processes and Resource Ecology.

\section{Author Contributions}

The research topic was discussed and decided by Chiyuan Miao and Alistair G.L. Borthwick. Honghu Liu and Jigen Liu made important recommendations regarding the paper structure. Alistair G.L. Borthwick also contributed primarily to the discussion on the environmental biodiversity 
consequences of dams along the Yellow River, the Yangtze River, and the Mekong River. The major part of this manuscript was completed by Chiyuan Miao.

\section{Conflicts of Interest}

The authors declare no conflict of interest.

\section{References}

1. Berga, L.; Buil, J.M.; Bofill, E.; Cea, J.C.D.; Perez, J.A.G.; Mañueco, G.; Polimon, J.; Soriano, A.; Yagüe, J. Dams and Reservoirs, Societies and Environment in the 21st Century; Taylor \& Francis Press: London, UK, 2006.

2. Chao, B.F.; Wu, Y.H.; Li, Y.S. Impact of artificial reservoir water impoundment on global sea level. Science 2008, 320, 212-214.

3. Lehner, B.; Liermann, C.R.; Revenga, C.; Vorosmarty, C.; Fekete, B.; Crouzet, P.; Doll, P.; Endejan, M.; Frenken, K.; Magome, J.; et al. High-resolution mapping of the world's reservoirs and dams for sustainable river-flow management. Front. Ecol. Environ. 2011, 9, 494-502.

4. Ministry of Water Resources the People's Republic of China. China Water Statistical Yearbook 2011; China Statistics Press: Beijing, China, 2012; pp. 117-119. (In Chinese)

5. Wang, J.; Sheng, Y.W.; Gleason, C.J.; Wada, Y. Downstream Yangtze River levels impacted by Three Gorges Dam. Environ. Res. Lett. 2013, 8, doi:10.1088/1748-9326/8/4/044012.

6. China Three Gorges Project Corporation. China Three Gorges Corporation Annual Report 2010. Available online: http://www.ctgpc.com/file/Annual_Report_2010.pdf (accessed on 11 November 2011).

7. Qi, M.M.; Jiang, J.D. Summary of resettlement planning of three gorges project. Yangtze River 2013, 44, 16-20. (In Chinese)

8. United States Geological Survey. Geographical Overview of the Three Gorges Dam and Reservoir, China. Available online: http://pubs.usgs.gov/of/2008/1241/pdf/OF08-1241_508.pdf (accessed on 11 November 2011)

9. Fu, C.Z.; Wu, J.H.; Chen, J.K.; Qu, Q.H.; Lei, G.C. Freshwater fish biodiversity in the Yangtze River basin of china: Patterns, threats and conservation. Biodivers. Conserv. 2003, 12, 1649-1685.

10. Stone, R. Mayhem on the Mekong. Science 2011, 333, 814-818.

11. Li, K.F.; Zhu, C.; Wu, L.; Huang, L.Y. Problems caused by the Three Gorges Dam construction in the Yangtze River basin: A review. Environ. Rev. 2013, 21, 127-135.

12. Turvey, S.T.; Pitman, R.L.; Taylor, B.L.; Barlow, J.; Akamatsu, T.; Barrett, L.A.; Zhao, X.J.; Reeves, R.R.; Stewart, B.S.; Wang, K.X.; et al. First human-caused extinction of a cetacean species? Biol. Lett. 2007, 3, 537-540.

13. Miao, C.Y.; Ni, J.R.; Borthwick, A.G.L. Recent changes of water discharge and sediment load in the Yellow River basin, china. Prog. Phys. Geogr. 2010, 34, 541-561.

14. Liu, C.; Zhang, X. Causal analysis on actual water flow reduction in the mainstream of the Yellow River. Acta Geogr. Sin. 2004, 59, 323-330. 
15. Ni, J.R.; Liu, X.Y.; Li, T.H.; Zhao, Y.; Jin, L. Efficiency of sediment transport by flood and its control in the lower Yellow River. Sci. China Ser. E 2004, 47, 173-185.

16. Guo, Q.Y.; Yang, Z.F. Post-project ecological analysis for the Sanmenxia Dam. Acta Sci. Circumst. 2005, 25, 580-585.

17. Ru, H.J.; Wang, H.J.; Zhao, W.H.; Shen, Y.Q.; Wang, Y.; Zhang, X.K. Fishes in the mainstream of the Yellow River: Assemblage characteristics and historical changes. Biodivers. Sci. 2010, 18, 169-174.

18. Lu, X.X.; Siew, R.Y. Water discharge and sediment flux changes over the past decades in the lower Mekong River: Possible impacts of the chinese dams. Hydrol. Earth Syst. Sci. 2006, 10, 181-195.

19. Wang, J.J.; Lu, X.X.; Kummu, M. Sediment load estimates and variations in the lower Mekong River. River Res. Appl. 2011, 27, 33-46.

20. Mekong River Commission. State of the basin report 2010. Available online: http://www. mrcmekong.org/assets/Publications/basin-reports/MRC-SOB-report-2010full-report.pdf (accessed on 11 November 2014).

21. Experts Worry about Mekong River Power Plant. Available online: http://en.qdnd.vn/news/ experts-worry-about-mekong-river-power-plant/139532.html (accessed on 11 November 2014).

22. Barrington, D.J.; Dobbs, S.; Loden, D.I. Social and environmental justice for communities of the mekong river. Int. J. Eng. Soc. Justice Peace 2012, 1, 31-49.

23. Mekong River Commission. Strategic Environmental Assessment of Hydropower on the Mekong Mainstream. Available online: http:/www.mrcmekong.org/assets/Publications/Consultations/ SEA-Hydropower/SEA-FR-summary-13oct.pdf (accessed on 13 January 2015)

24. Grumbine, R.E.; Xu, J.C. Mekong hydropower development. Science 2011, 332, 178-179.

25. Jia, J.S.; Yuan, Y.L.; Zheng, C.Y.; Ma, Z.L. Dam construction in China: Statistics, progresses and concerned issues. Water Power 2010, 36, 6-10.

26. Qiu, J. China unveils green targets. Nature 2011, 471, 149.

(C) 2015 by the authors; licensee MDPI, Basel, Switzerland. This article is an open access article distributed under the terms and conditions of the Creative Commons Attribution license (http://creativecommons.org/licenses/by/4.0/). 